Article

\title{
Migrants' Experiences With Limited Access to Social Protection in a Framework of EU Post-National Policies
}

\author{
Elisabeth Scheibelhofer \\ Department of Sociology, University of Vienna, Austria; elisabeth.scheibelhofer@univie.ac.at
}

Submitted: 27 July 2021 | Accepted: 9 December 2021 | Published: 22 March 2022

\begin{abstract}
It has been argued that nation-states confront migrant protection with a highly diverse array of measures ranging from excluding strategies (often labelled as "welfare chauvinism") to more inclusionary, post-national approaches. While exclusionary strategies are often guided by nativist principles such as citizenship, post-national approaches of social protection are usually based on residence. Building on an international comparative project with a focus on free movement within the European Union, and involving four pairs of EU member states, this article argues that the extremes of these two ways of understanding nation-state approaches to migrant social protection are not mutually exclusive, as has been discussed so far, but, instead, are intertwined with one another. While there is a common (and globally unique) framework on the EU level for the coordination of mobile citizens' social protection, EU member states determine their strategies using residence as a main tool to govern intra-EU migration. We differentiate between three main intertwining strategies applied by nation-states in this respect: generally, selectively, and purposefully gated access to social protection. All three potentially lead to the social exclusion of migrants, particularly those who cannot prove their residence status in line with institutional regulations due to their undocumented living situations or their transnational lifestyles.
\end{abstract}

\section{Keywords}

citizenship; EU free movement; migrants; social protection; welfare chauvinism

\section{Issue}

This article is part of the issue "Transnational Social Protection: Inclusion for Whom? Theoretical Reflections and Migrant Experiences" edited by Elisabeth Scheibelhofer (University of Vienna), Emma Carmel (University of Bath), and Anna Amelina (University of Cottbus).

(C) 2022 by the author(s); licensee Cogitatio (Lisbon, Portugal). This article is licensed under a Creative Commons Attribution 4.0 International License (CC BY).

\section{Introduction}

How is it possible that the citizens of a European Union member state or a country within the European economic area (EEA) are still discriminated against in terms of their social protection when they migrate within the EU? Legally, they are protected by EU regulations for transnational social security that are unique compared to other nation-states worldwide and based on post-national policies enacted by the EU. In this article, we use the term "social security" for provisions of nation-states in a narrower sense, while the term "social protection" encompasses an elaborate network of governmental, private, and intermediary institutions (Levitt et al., 2017). Unlike other nation-states around the world,
EU member states have agreed to ban discrimination based on citizenship (among them and for their citizens only). However, recent empirical research shows that equal treatment is not an unflawed social reality for EU migrants trying to access their social rights in another EU member state (see, for example, Kramer, 2020). In this article, we examine the two extreme positions in this debate to understand the differences between nationstates in terms of migrant access to social protection: the post-national welfare state and the chauvinist welfare state. Recently, especially the concept of a chauvinist welfare state has been rightly criticised, pointing to the need for further clarification (Carmel \& Sojka, 2021). Until now, these two approaches have been considered in opposition to each other, but we argue that they are 
two mechanisms working together. As such, the intertwining of the two mechanisms contribute in complex and manifold ways to the exclusion of specific groups from social protection and, thus, create further social inequalities within European societies.

It has been argued that, while EU regulations and the rulings of the European Court of Justice on issues of social welfare for migrants are based on a post-national spirit, they also lay the foundation for more exclusionist policies effected on a national level by EU member states (Favell, 2014, 2016). In particular, right-wing and conservative governments create regulations that have nationally chauvinist outcomes. Such strategies imply that the regulations aim to establish the difference between natives and non-natives. Since such differentiation is not compatible with EU legislation and jurisdiction; certain EU member states use the main pillar of a post-national principle to achieve nationalist ends. As a result, residence becomes a contested issue, based on which EU migrants are often excluded from social protection. As EU regulation itself is based heavily on residence and simultaneously postulates that eligibility is decided on a case-by-case basis, EU migrants are frequently placed under scrutiny by street-level bureaucrats.

\section{Are the Extremes of Post-National and Chauvinist Welfare State Strategies Mutually Exclusive?}

While there has been a discussion, primarily in social policy research, about the relationship between different types of welfare states (De Giorgi \& Pellizzari, 2009; Sainsbury, 2006) and the provision of social protection for migrants, the debate on welfare state chauvinism has more recently gained momentum (Carmel \& Sojka, 2021; Favell, 2016; Kymlicka, 2015). Schmitt and Teney (2019) argue that the differences between nation-state responses in terms of migrant access to social protection can be classified under two opposing theories: the theory of welfare state chauvinism and the theory of post-national approaches. Welfare state chauvinism is based on the idea that social protection should be exclusively provided for those who are considered "natives" of the respective nation-state. Such a nationalist model is perceived by some as necessary in light of political movements towards closure and restriction against foreign-born persons, both across Europe and in other parts of the world (De Koster et al., 2013; Hjorth, 2016; Mau, 2007).

In contrast to this position, scholars have argued that nation-states also deal with issues of migrant welfare using post-national logic. From this perspective, rights are based on physical presence within state territory, which does not necessarily coincide with nativism or citizenship (Obermaier, 2016). In particular, the modus operandi of the EU has been put forward as an example of a post-national model (Favell, 2014, 2016). Concerning the situation of mobile citizens within the EU, Adrian Favell also stressed that, even though everyday racism might still result in individual instances of discrimination, the regulations in place assure that the state cannot discriminate against migrants based on their citizenship. In light of recent developments within the EU (e.g., Brexit, the rise of right-wing nationalist parties, and the difficulties of the EU to find more common ground in important policy areas such as migration), many scholars have criticised the analysis of the EU as a post-national space (Auer, 2010; Edmunds, 2012; Koopmans, 2018; Pinelli, 2013; Tonkiss, 2019).

Apart from these discussions on the post-national character of the EU, the national dimension plays an important role for intra-EU migrants' welfare state provisions, as they are usually confronted with a multilayered policy outcome. Empirical research has thus provided us with a complex, ample picture of different patterns to be observed when it comes to national policies in this respect (Heindlmaier \& Blauberger, 2017; Kramer, 2020; Kramer \& Heindlmaier, 2021). The process is furthermore complicated by the fact that multilevel governance is not unidirectional: There are multiple players within EU institutions, while nation-state actors intervene in the decision-making processes in various ways and at different levels (Carmel et al., 2011). Thus, the "ground-level" regulations with which individual EU migrants are confronted on a daily basis take different shapes and forms depending on the member state's welfare history, actual procurement of benefits, and transnational exchange with the institutions of the migrant's birthplace. The post-national concept, therefore, suggests the idea of membership to a community that is no longer defined by citizenship, but by residence (for the changing significance see, in detail, Joppke, 1998; Soysal, 1994).

Until now, it has been argued that these two approaches contradict each other (see, e.g., Schmitt \& Teney, 2019). At first glance, this would seem logical, as the modes of differentiation are clear-cut and opposing: While the post-national welfare state makes distinctions along the lines of residence, the chauvinist welfare state does so based on citizenship (for the implications for solidarity in larger groups see Kymlicka, 2015). Yet our research suggests that these two modes of differentiation, as to who should have access to national welfare and who should not, are, in fact, both at work when analysing the actual experiences of EU citizens who migrate to another EU member state.

\section{Current Social Protection for EU Migrants}

As migration increases globally, so does the need for social protection for migrants over their life course. Research has emphasised the presence of a clear North-South divide in terms of provisions for transnational social protection worldwide (Avato et al., 2010; Blauberger \& Schmidt, 2014; Faist et al., 2015; Giulietti, 2014; Lafleur \& Romero, 2018; Paul, 2017; Römer, 2017; Ruist, 2014; Serra Mingot \& Mazzucato, 2019). 
While many bilateral agreements on social protection for migrants have been concluded (Sabates-Wheeler \& Koettl, 2010; Sabates-Wheeler et al., 2011; Sainsbury, 2006), the EU is usually referred to as the best-practice example in the seminal literature within diverse disciplines such as law, economics, and the social sciences (Blauberger \& Schmidt, 2014; Carmel et al., 2011; De Giorgi \& Pellizzari, 2009; Ferrera, 2016; Heindlmaier \& Blauberger, 2017; Hjorth, 2016; Schmidt et al., 2018; Serra Mingot \& Mazzucato, 2018).

On the complex legal basis of the EU, it is the duty of member states to create and enact national laws and regulations following EU policy. Thus, member states devise various ways to implement laws, opting either for more strict or more laissez-faire national solutions (Amelina et al., 2019; Carmel \& Paul, 2013). A case-by-case principle applies if a citizen does not feel correctly treated by a member state. An EU citizen moving to another EU member state is thus confronted with complex and often opaque regulations (Carmel et al., 2019) when trying to access social security rights. This article is based on the experiences of migrants who are mobile between two specific EU countries. When analysing the migrant perspective on navigating two national welfare systems, how welfare chauvinist ends can be reached through national interpretations of post-national EU regulations became apparent. The key aspects in this respect are how "residence" is constructed and perceived by EU and national institutions, as well as what the implications of this construct are for migrants.

To solve the question as to which member state is responsible for the provision of social benefits, national welfare institutions are obliged to establish each applicant's "habitual residence." However, the criteria for residence are general and by no means clear-cut (Carmel et al., 2016). In article 11 of EU Regulation 987/2009, these criteria refer to the following: family situation, duration and continuity of presence in a member state, employment situation, exercise of non-remunerated activity, the permanent character of the housing situation, and intention of the person to reside as it appears from all the circumstances. Based on these rather vague indications, national institutions may conclude that a given individual's centre of vital interests, and thus their residence, is located in another member state. If the workplace is in yet another member state, the person qualifies as a frontier worker. In practice, such categorisations may occur when close family members live in different member states or when individuals frequently travel to another nation-state. The decision on the centre of vital interests is indeed wide-ranging, as it is up to the authorities of the country in which the centre of vital interests is located to pay unemployment benefits. Especially in the context of migration from "new" member states to "old" member states, such decisions impact the life chances of many EU migrants significantly, since the levels of social benefits in the "new" member states are usually only a fraction of those in the "old" member states (Bruzelius et al., 2018; Seeleib-Kaiser \& Pennings, 2018).

What we saw through our empirical research is that national regulations, as well as their application by streetlevel bureaucrats, varied greatly across the four "old" receiving EU member states we studied. These states were part of the following four country pairs: HungaryAustria, Poland-UK, Bulgaria-Germany, and EstoniaSweden. For all interviewed migrants seeking social protection in one of these four member states, place of residence was the main barrier. Research on other EU countries has suggested that the four "old" member states examined in this article are not the only ones that use residence as a basis to build measures that ultimately function as exclusionary mechanisms towards "foreign" EU citizens. Lafleur and colleagues, for example, report such issues for Belgium as well, where residence tests led to the expulsion of several thousands of Italians (Lafleur \& Mescoli, 2018; Lafleur \& Stanek, 2017). So far, however, the literature on the experiences of migrants themselves is rather scarce and not comparative in this respect.

\section{Empirical Basis of the Argument}

Our empirical research project was designed to study the experiences of EU migrants moving from a "new" EU member state to an "old" EU member state (Scheibelhofer \& Holzinger, 2018). At the core of this project was an interest in scrutinising the provision and execution of cross-border welfare rights within four country pairs. The country pairs were selected due to ongoing discussions of welfare migration from "new" to "old" member states; additionally, they were chosen based on their differences in terms of welfare state regimes and forms of migration (Faist, 2017). We expected to find ensuing differences in the cross-border social security access of mobile EU citizens. Thus, the "old" countries of immigration were selected to address different welfare state regimes and to provide a contrast between "old" countries holding strict labour market restrictions for EU migrants (Austria and Germany) and those that are less restrictive in this regard (UK and Sweden). In turn, "new" countries of emigration were selected based on their differing migration histories as compared to the respective "old" sending countries. The selected country pairings already mentioned above were based on the assumption that migration history influences the organisational structures of diasporic communities, which then play an important role in providing relevant information on access to social security rights.

Concerning the selection of interview partners, theoretical sampling strategies were employed that were embedded in a circular research methodology based on the research perspective of constructivist grounded theory (Charmaz, 2006). We carried out problem-centred interviews (Scheibelhofer, 2008; Witzel \& Reiter, 2012) with a total of 81 migrants between the winter of 2015 and the end of 2016 . 


\section{Three Mechanisms of Excluding EU Foreigners Based on Assumptions of Residence}

We perceive "residence" here as a spatial-social construct (see Massey, 1999, 2005). This construct is produced by diverse political and administrative actors on different levels and, due to this construction, welfare institutions determine, through application and interpretation, whether or not an individual should receive benefits. The meaning of spatial concepts has previously been discussed in the context of intra-EU migration (Scheibelhofer, 2016). Our focus in the present investigation is how such a (politically and administratively enforced) concept of space is experienced by EU migrants themselves once they try to access social benefits. Based on our empirical research, we propose that post-national and welfare chauvinist approaches are in practice entangled with one another, given that post-national policy-making based on residence is used to restrict access for migrants between EU member states.

In addition, we address the issue as to how member states respond to greater welfare rights of EU citizens. Recent research has indicated that member states mostly rely on strategies of restricting EU citizens' access by "quarantining" them instead of using more inclusive responses (Kramer et al., 2018). Based on our empirical research, we make a conceptual contribution by defining such "quarantining" more precisely: We propose three different approaches as to how welfare states turn the post-national dimension of residence into a means to limit access to welfare systems. We would not have been able to arrive at these conclusions via a top-down policy analysis, as some exclusionary mechanisms cannot be directly derived from the policy frameworks targeting EU free-movers and, thus, have not been part of the scholarly debate. By taking the migrants' perspective as a point of departure, we were able to trace the implications of these counter-intuitive exclusionary practices for individuals. In the following, we describe the peculiarities of each type of residence-based limitation on migrants' access to social benefits across the EU, utilizing the case studies generated to describe the complex functioning of these exclusionary mechanisms.

\subsection{Generally Gated Access to Social Benefits: The Swedish PIN System}

The interplay of overall welfare administrative regulations on the one hand and the living conditions of EU migrants on the other can play out in such a way that specific mobile groups are excluded from accessing social security. This is often the case for transnational EU migrants who have usually more than one centre of vital interest.

An empirical example for such a situation was found in Sweden (the TRANSWEL project in Sweden has been carried out by the team of Ann Runfors, Florence Fröhig, and Maarja Saar; see also Fröhlig et al., 2020):
The Personal Identification Number (PIN) system was not set up to manage migration per se, as all newborns in Sweden receive a PIN. Many social services and benefits are automatically provided to PIN holders but are not accessible to those without such an identification. Once a person moves to Sweden, they have to apply for a PIN in order to access (nearly) any social benefit. This is the case for all migrants, including EU citizens. Concession requirements play out in a very complex manner (Runfors et al., 2016). To put a long institutional history short, PINs are only granted if EU citizens with the intention of moving to Sweden can prove to have both a work contract of at least one year, as well as accommodation. Nevertheless, employers face difficulties when attempting to hire individuals without a PIN, and landlords also prefer tenants with PINs or, in the absence of a PIN, who hold steady employment. As a consequence, EU citizens have a hard time obtaining a PIN when migrating to Sweden. Although this problem was common amongst the interview partners, this major obstacle has been barely discussed in the pertinent literature (for an exception see Spehar et al., 2017).

Based on the empirical data uncovered through our research, we concur with existing research results indicating that transnational lifestyles within the EU are part of many migrants' everyday lives (Goldring, 2017; Kraal \& Vertovec, 2017). Migrants may have domiciles in two EU member states, or they may have close family members whom they try to see as often as their jobs in the "old" member states permit. Indeed, some of our interview partners travelled regularly to their countries of origin for these reasons. This was true for many Estonian citizens working and/or living in Sweden. Thus, the very concept of having one single and exclusive "centre of vital interests," as envisaged by multilevel EU social policy coordination, is problematic. As a result, individuals may face difficulties when attempting to provide proof of employment and residence in Sweden to the extent requested by regulations and street-level bureaucrats in charge.

In our study, problems receiving a PIN arose especially for individuals involved in transnational family arrangements, as legal baselines to prove a centre of vital interests include close family members' residence. In our sample, 47-year-old Estonian citizen, Raivo, experienced such difficulties: At the time of the interview, he was employed as a construction worker in Sweden, while his wife and two teenage children were living in Estonia. He encountered difficulties applying for a PIN because of the specific interpretation, by the Swedish administration, of how proper family arrangements should be in spatial terms:

They had a problem there that my family is in Estonia, children are in Estonia. One child was younger than 18 by then. And that was it. And then they started telling me in connection with the marriage that, Jesus Christ, how can it be that your wife is there and you are here. (Raivo, 47 years, Estonia/Sweden) 
Transnational family arrangements, by now, form part of migrants' social lives, as empirical research in Europe has widely shown (Kilkey \& Merla, 2014; Kraler \& Bonizzoni, 2010; Ryan, 2011). Raivo was not the only interview partner in our sample to live a transnational family life. While regionally separated household compositions within one nation-state (e.g., commuting on a daily or weekly basis within one nation-state) are not constructed as socially problematic in terms of accessing social security, crossing EU-borders when commuting becomes an issue for the "mobility" of EU citizens within the current policy framework. This is due to the concept of the centre of vital interests as laid down in EU regulations on accessing social benefits and its implications on a national level. In Sweden, the centre of vital interests is also inherent in national PIN legislation, which is in line with EU regulations, and therefore must be adhered to by EU citizens. Thus, policies with welfare chauvinist effects are not visible at first glance but have direct implications for the life chances of migrants even within the EU.

\subsection{Selectively Gated Access to Social Benefits: The Austrian Registration Certificate System}

Access can be selectively gated for EU migrants in instances where regulations are complex and might not be easily understood by individuals. Not conforming to obligations at certain points in time might, later on, lead to serious problems in terms of securing access to social benefits.

With the latest rounds of EU enlargement, Austria introduced a new national regulation in 2006 requiring EU citizens who wish to stay for longer than three months to apply for a registration certificate (Anmeldebescheinigung). EU migrants without employment or those who are self-employed are required to account for sufficient means of subsistence and health insurance coverage for themselves and their family members. In accordance with the maximum length defined by EU regulations, migrants (under certain circumstances) need to be registered for a five-year period in order to apply for a certificate of permanent residence (Bescheinigung des Daueraufenthalts). It is only after this period that EU citizens may apply for means-tested benefits in case they were not regularly employed before this period (Blauberger \& Schmidt, 2014; Heindlmaier \& Blauberger, 2017).

Through our qualitative interviews, we found that the interview partners living in Austria were rarely aware of this registration for a lawful stay in Austria. This is the case because registration regulations and ensuing obligations are manifold and complex. Any person in Austria who intends to stay at a given address for more than three nights needs to report their stay with the local authority (compulsory housing registration or Meldepflicht). This law also applies to EU citizens, as it does to nationals or third-country nationals. On top of this general registration obligation, EU citizens intending to stay for more than three months must register an additional time, which adds confusion as we saw in our interviews. No automatic communications are sent to the persons who register in the first place that they need to do so a second time. Whether EU migrants learn about their obligation to apply for registration certificates depends on street-level bureaucrats' decision to share this crucial information, or migrants' ability to find it through personal contacts or by means of a rather difficult internet research.

In our qualitative interviews with Hungarians living in Vienna, we found several cases in which individuals were not covered by welfare regulations because they had not registered as EU citizens. As a paradigmatic example, we draw here on the case of Virág who, at the time of the interview, had been living in Austria for 17 years and still lacked full access to social benefits due to registration issues. She was 62 years old at the time and working as a housekeeper in private residences on a semi-legal basis. Furthermore, her living arrangement, an unofficial sublet, prevented her from registering. When we accompanied her to the Austrian Pension Fund, she was told that she needed a proper housing registration and employment contract. With the help of an NGO, she was able to provide a rental contract and transfer one of her jobs into lawful employment. The street-level bureaucrats used their leeway of decision-making power in her favour and provided her-after one year of constant back and forth between institutions - with access to a small pension she could live on. Virág was relieved about this decision as, at that time, she was no longer able to work because of progressive Parkinson's disease. Having kept track of Virág's journey throughout this project, we can report that the process turned out to her benefit, yet the regulations on residence would have also allowed for a less favourable decision by the street-level bureaucrats (Lipsky, 2010; Smith, 2003).

Granting selectively gated access means that additional restrictive policies are put in place on a national level to restrict the access theoretically granted to social benefits on an EU level in a post-national spirit. Once again, the effect on the migrant can be an exclusionary one if the individual is in an inferior position in terms of information and legal knowledge.

\subsection{Purposefully Gated Access to Social Benefits: Institutionalised Targeted Residence Tests in the UK and Austria}

As described above, the principle of granting access to social benefits based on residence and not based on citizenship is inherently post-national in character. Yet, also the third type of residence-based exclusionary policy consists of purposefully gated access realising welfare chauvinist aims based on residence. These regulations only affect EU citizens if they apply for a certain social benefit. While the PIN system in Sweden is applied to every newborn native and each individual moving to Sweden, 
and while the Austrian registration certificate must be applied for by each EU citizen, targeted residence tests have been introduced in all four immigration countries under investigation; nonetheless, we found the most pronounced testing regulations in the UK and Austria.

In 2004, the habitual residence test (HRT) was introduced in the UK to limit access to social benefits for citizens of the accession countries (Carmel et al., 2016; Larkin, 2009; O'Brien, 2015). The HRT is administered amongst EU citizens who apply for certain means-tested benefits. To pass the test, migrants need to show that they have a right to live in the UK (O'Brien, 2016) and that they intend to settle. If an individual owns a house in their own country, they may fail the test, as the intention to reside permanently may not be assumed.

By way of qualitative interviews with migrants, our colleagues in the UK (Emma Carmel, Bozena Sojka, and Kinga Papiez) established that passing the HRT could be challenging, as street-level bureaucrats had a rather large amount of decision-making leeway, which several interview partners found was used against them. Cezary, for example, was asked whether he owned property in Poland and indicated that he had a flat he used when staying there. HRT regulations are not strict in terms of how such information should influence the outcome of the test, which means that authorities are relatively free to make a decision. During the UK team's interview with Cezary, further details were revealed that the street-level bureaucrat may not have been aware of when turning down Cezary's request:

In the council, they asked about property in Poland....I made a mistake, because I told them that I have a studio flat in Poland. But this studio flat is a council flat, not my own. They added something to the files and, after that, I received no more help from them. I sent also documents from Poland. I sent documents from the council to prove that I do not claim any benefits and any additional housing support in Poland. (Cezary, 35 years, Poland/UK)

As mentioned above, such purposefully gated access based on residence was also identified when carrying out the empirical study in Austria, although the situation in terms of residence tests differed from the one described above for the UK. While the receipt of Austrian unemployment benefits is tied to presence in the national territory (so that the unemployed can search properly for jobs), "presence" is an ambiguous term especially in a highly transnational region such as Western Hungary and Eastern Austria. Thus, the term in itself needs further legal interpretation. For example, travelling back and forth the same distance on weekdays but staying in an Austrian location on the weekend poses no trouble to those entitled to unemployment benefits. Our interview partners who spent their weekends in Hungary when unemployed could be categorised as "frontier workers" according to EU regulations. As a consequence, Austria would no longer provide unemployment benefits and the given individual would fall under Hungarian jurisdiction. The Hungarian interview partners were, therefore, threatened that they might lose their entitlement to Austrian unemployment benefits which were nearly four times higher than those administered in Hungary (Regös et al., 2019).

As we observed during 17 months of fieldwork in Vienna, our interview partners found their cases under ever-increasing scrutiny when applying for unemployment benefits; furthermore, they were forced to defend themselves against the suspicion of having their "centre of vital interests" in Hungary. Most notably, a form designed to aid the Austrian Employment Service (AMS) in deciding whether or not Austria is responsible for providing unemployment benefits was introduced during the period of our research and was modified several times, as our data indicate. The form is described in detail in the following citation by Szabolcs, a 27-year-old Hungarian university graduate who had to pass the residence test at a local unemployment service office in Vienna:

They gave me a document about how often I travel to Hungary, whether I have a Hungarian car, ahm, how many days I spend here, whether I have a flat in Hungary, who of my relatives live in Hungary, and I, in this situation, I felt that NOBODY EVER asked me these questions. And this was the first moment when I felt that, damn it, I am a miserable Eastern European in the eyes of the administrator. (Szabolcs, 27 years, Hungary/Austria)

Although not detailed explicitly in the form, the contained questions are in line with the criteria agreed upon in the European social security coordination regulations (as mentioned above in article 11 of EC 987/2009; see also Carmel et al., 2016) to identify a "centre of vital interests" (Scheibelhofer \& Holzinger, 2018). The introduction of this questionnaire was not announced on the website of the AMS or otherwise communicated to Szabolcs. Thus, his experience resulted in a feeling of arbitrariness and discrimination based on his being perceived as an Eastern European.

\section{Conclusions}

Our empirical research concurs with other recent investigations (Bruzelius et al., 2017; Ehata \& Seeleib-Kaiser, 2017; Heindlmaier \& Blauberger, 2017; Kramer et al., 2018; Pavolini \& Seeleib-Kaiser, 2018; Shutes \& Walker, 2018), showing that the intra-European promise of social security in the event of migration frequently fails in practice to lead to a post-national model of social protection. Rather, we suggest that we are confronted with an intertwining of welfare chauvinist and post-national strategies resulting in limited social security for those who migrate. This is a noteworthy finding, as antidiscrimination laws have been in place for many years and EU 
member states have agreed upon a coordination system for EU citizens' social benefits (under certain conditions). We thus conclude that the description of EU politics as post-national (Favell, 2016) does not provide the whole picture and is not an adequate framework when accounting for the actual experiences of EU citizens who migrate within the EU. We see that we need to take into account the complex multilevel policies and how they play out in the end for mobile individuals. Our investigation yields detailed insights on how residence is used as a differentiator on various policy levels to exclude non-nationals from social welfare provisions.

In this article, we have argued that, on the basis of the post-national principle of residence, discrimination towards EU non-nationals still occurs due to welfare chauvinist ambitions of EU member states to exclude the "unwanted." Based on qualitative interviews with EU migrants in different EU countries, we proposed three different concepts of how residence is used by institutions of member states to exclude EU citizens from such provisions. As empirical research on migration and mobility has shown, many migrants fit the definition of "resident" currently in use within the multiple levels of EU politics. Those who arrive with a work contract, as well as those who are supported by their future employers, may not encounter major difficulties in accessing social protection and may not even be aware of the spatial restrictions for legal settlement (Runfors et al., 2016). However, most mobile Europeans from "new" member states face welfare chauvinist national policies and thus cannot enjoy freedom of movement without discrimination, as envisaged in the above-cited EU regulations and principles. We understand that a main difficulty for migrants arises due to the multiple definitions of "centre of vital interests." These definitions vary and can have multiple meanings, even within the same member state (Regös et al., 2019). Yet all definitions share a common denominator, highlighted in the EU coordination of social security: "Centre of vital interest" only exists in the singular and plurality is not foreseen. Thus, migrants who lead highly mobile or transnational lives are most vulnerable once they try to access social security, as they often encounter difficulties when attempting to adequately prove their centre of vital interests. This is even more true for those who live in transnational families. Thus, having multiple places of residence often becomes a serious obstacle in accessing social security, at least in the case that a national border with a "new" EU member state separates an individual from their family.

\section{Acknowledgments}

The three-year research project TRANSWEL (2015-2018) was funded by NORFACE via FWF collaboration (FWF project number I 2025-G16). We wish to thank our colleagues from the TRANSWEL team (www.transwel.org) for their contribution to this project, especially Emma Carmel, Anna Amelina, and Ann Runfors. We also thank the University of Vienna for the funding of the open access costs of this article. Thanks are also due to (again) Emma Carmel, Clara Holzinger, and two anonymous reviewers for their critical and helpful feedback in the development of this contribution.

\section{Conflict of Interests}

The author declares no conflict of interests.

\section{References}

Amelina, A., Carmel, E., Runfors, A., \& Scheibelhofer, E. (Eds.). (2019). Boundaries of European social citizenship: EU citizens' transnational social security in regulations, discourses and experiences. Routledge.

Auer, S. (2010). "New Europe": Between cosmopolitan dreams and nationalist nightmares. JCMS: Journal of Common Market Studies, 48(5), 1163-1184.

Avato, J., Koettl, J., \& Sabates-Wheeler, R. (2010). Social security regimes, global estimates, and good practices: The status of social protection for international migrants. World Development, 38(4), 455-466.

Blauberger, M., \& Schmidt, S. K. (2014). Welfare migration? Free movement of EU citizens and access to social benefits. Research \& Politics, 1(3), 1-7. https:// doi.org/2053168014563879

Bruzelius, C., Jacqueson, C., \& Seeleib-Kaiser, M. (2018). (Dis)united in diversity? Social policy and social rights in the EU. In F. Pennings \& M. Seeleib-Kaiser (Eds.), EU citizenship and social rights (pp. 51-75). Edward Elgar Publishing.

Bruzelius, C., Reinprecht, C., \& Seeleib-Kaiser, M. (2017). Stratified social rights limiting EU citizenship. JCMS: Journal of Common Market Studies, 55(6), 1239-1253.

Carmel, E., Cerami, A., \& Papadopoulos, T. (2011). Migration and welfare in the new Europe: Social protection and the challenges of integration. Policy Press.

Carmel, E., \& Paul, R. (2013). Complex stratification: Understanding European Union governance of migrant rights. Regions and Cohesion, 3(3), 56-85.

Carmel, E., \& Sojka, B. (2021). Beyond welfare chauvinism and deservingness. Rationales of belonging as a conceptual framework for the politics and governance of migrants' rights. Journal of Social Policy, 50(3), 645-667.

Carmel, E., Sojka, B., \& Papiez, K. (2016). Free to move, right to work, entitled to claim? Governing social security portability for mobile Europeans (WSF Report). TRANSWEL.

Carmel, E., Sojka, B., \& Papiez, K. (2019). Beyond the rights-bearing EU mobile citizen: Governing inequality and privilege in European Union social security. In A. Amelina, E. Carmel, A. Runfors, \& E. Scheibelhofer (Eds.), Boundaries of European social citizenship: EU citizens' transnational social security in regulations, discourses and experiences (pp. 46-72). Routledge. 
Charmaz, K. (2006). Constructing grounded theory: A practical guide through qualitative analysis. SAGE.

De Giorgi, G., \& Pellizzari, M. (2009). Welfare migration in Europe. Labour Economics, 16(4), 353-363.

De Koster, W., Achterberg, P., \& Van der Waal, J. (2013). The new right and the welfare state: The electoral relevance of welfare chauvinism and welfare populism in the Netherlands. International Political Science Review, 34(1), 3-20.

Edmunds, J. (2012). The limits of post-national citizenship: European Muslims, human rights and the hijab. Ethnic and Racial Studies, 35(7), 1181-1199.

Ehata, R., \& Seeleib-Kaiser, M. (2017). Benefit tourism and EU migrant citizens: Real-world experiences. In J. Hudson, C. Needham, \& E. Heins (Eds.), Social policy review 29: Analysis and debate in social policy (pp. 181-198). Bristol University Press, Policy Press.

Faist, T. (2017). Transnational social protection in Europe: A social inequality perspective. Oxford Development Studies, 45(1), 20-32.

Faist, T., Bilecen, B., Barglowski, K., \& Sienkiewicz, J. J. (2015). Transnational social protection: Migrants' strategies and patterns of inequalities. Population, Space and Place, 21(3), 193-202.

Favell, A. (2014). The fourth freedom: Theories of migration and mobilities in "neo-liberal" Europe. European Journal of Social Theory, 17(3), 275-289.

Favell, A. (2016). Liberalism not neo-liberalism: Comment on Will Kymlicka's article "Solidarity in diverse societies." Comparative Migration Studies, 4(1). https://doi.org/10.1186/s40878-016-0026-y

Ferrera, M. (2016). The contentious politics of hospitality: Intra-EU mobility and social rights. European Law Journal, 22(6), 791-805.

Fröhlig, F., Saar, M., \& Runfors, A. (2020). Business contract meets social contract. In A. Amelina, E. Carmel, A. Runfors, \& E. Scheibelhofer (Eds.), Boundaries of European social citizenship: EU citizens' transnational social security in regulations, discourses and experiences (pp. 181-198). Routledge.

Giulietti, C. (2014). The welfare magnet hypothesis and the welfare take-up of migrants. IZA World of Labor, 2014(June). https://doi.org/10.15185/izawol.37

Goldring, L. (2017). The power of status in transnational social fields. In M. P. Smith (Ed.), Transnationalism from below (pp. 165-195). Routledge.

Heindlmaier, A., \& Blauberger, M. (2017). Enter at your own risk: Free movement of EU citizens in practice. West European Politics, 40(6). https://doi.org/ 10.1080/01402382.2017.1294383

Hjorth, F. (2016). Who benefits? Welfare chauvinism and national stereotypes. European Union Politics, 17(1), 3-24.

Joppke, C. (1998). Immigration challenges the nation-state. In C. Joppke (Ed.), Challenge to the nation-state (pp. 5-46). Oxford University Press. https://doi.org/10.1093/0198292295.001.0001

Kilkey, M., \& Merla, L. (2014). Situating transnational fam- ilies' care-giving arrangements: The role of institutional contexts. Global Networks, 14(2), 210-229.

Koopmans, R. (2018). Cultural rights of native majorities between universalism and minority rights (WZB Discussion Paper). Wissenschaftszentrum Berlin für Sozialforschung. https://www.econstor.eu/handle/ 10419/194003

Kraal, K., \& Vertovec, S. (2017). Citizenship in European cities: Immigrants, local politics and integration policies. Routledge.

Kraler, A., \& Bonizzoni, P. (2010). Gender, civic stratification and the right to family life: Problematising immigrants' integration in the EU. International Review of Sociology, 20(1), 181-187.

Kramer, D. (2020). Earning social citizenship: Free movement, national welfare and the European Court of Justice [PhD thesis, Vrije Universiteit Amsterdam]. Narcis: Open Access. https://research.vu.nl/ en/publications/earning-social-citizenship-freemovement-national-welfare-and-the

Kramer, D., \& Heindlmaier, A. (2021). Administering the Union citizen in need: Between welfare state bureaucracy and migration control. Journal of European Social Policy. Advance online publication. https://doi. org/10.1177/0958928721999612

Kramer, D., Sampson Thierry, J., \& Van Hooren, F. (2018). Responding to free movement: Quarantining mobile union citizens in European welfare states. Journal of European Public Policy, 25(10), 1501-1521.

Kymlicka, W. (2015). Solidarity in diverse societies: Beyond neoliberal multiculturalism and welfare chauvinism. Comparative Migration Studies, 3(1). https://comparativemigrationstudies.springeropen. com/articles/10.1186/s40878-015-0017-4

Lafleur, J.-M., \& Mescoli, E. (2018). Creating undocumented EU migrants through welfare: A conceptualization of undeserving and precarious citizenship. Sociology, 52(3), 480-496.

Lafleur, J.-M., \& Romero, M. V. (2018). Combining transnational and intersectional approaches to immigrants' social protection: The case of Andean families' access to health. Comparative Migration Studies, 6(1). https://doi.org/10.1186/s40878-018-0073-7

Lafleur, J.-M., \& Stanek, M. (2017). Restrictions on access to social protection by new southern European migrants in Belgium. In J.-M. Lafleur \& M. Stanek (Eds.), South-North migration of EU citizens in times of crisis (pp. 99-121). Springer.

Larkin, P. (2009). A policy of inconsistency and hypocrisy: United Kingdom social security policy and European citizenship. Journal of Social Welfare \& Family Law, 31(1), 33-45.

Levitt, P., Viterna, J., Mueller, A., \& Lloyd, C. (2017). Transnational social protection: Setting the agenda. Oxford Development Studies, 45(1), 2-19.

Lipsky, M. (2010). Street-level bureaucracy, dilemmas of the individual in public service. Russell Sage Foundation. 
Massey, D. (1999). Imagining globalisation: Powergeometries of time-space. In D. Massey (Ed.), Powergeometries and the politics of space-time. HettnerLecture 1998 (pp. 9-2). Department of Geography, University of Heidelberg.

Massey, D. (2005). For space. SAGE.

Mau, S. (2007). Mitgliedschaftsräume, wohlfahrtsstaatliche Solidarität und Migration [Spheres of affiliation, welfare state solidarity, and migration]. In D. Mackert (Ed.), Moderne (Staats-)Bürgerschaft. Nationale Staatsbürgerschaft und die Debatten der Citizenship Studies [Modern citizienship. National citizienship and the debates in citizienship studies] (pp. 215-233). Springer.

O'Brien, C. (2015). The pillory, the precipice and the slippery slope: The profound effects of the UK's legal reform programme targeting EU migrants. Journal of Social Welfare and Family Law, 37(1), 111-136.

O'Brien, C. (2016). Civis capitalist sum: Class as the new guiding principle of EU free movement rights. Common Market Law Review, 53(4), 937-977.

Obermaier, A. J. (2016). The end of territoriality? The impact of ECJ rulings on British, German and French social policy. Routledge.

Paul, R. (2017). Welfare without borders: Unpacking the bases of transnational social protection for international migrants. Oxford Development Studies, 45(1), 33-46.

Pavolini, E., \& Seeleib-Kaiser, M. (2018). Comparing occupational welfare in Europe: The case of occupational pensions. Social Policy \& Administration, 52(2), 477-490.

Pinelli, C. (2013). The discourses on post-national governance and the democratic deficit absent an EU government. European Constitutional Law Review, 9(2), 177-188.

Regös, N., Holzinger, C., \& Scheibelhofer, E. (2019). When vicinity divides: Transnational social security in the cross-border region of Hungary and Austria. In A. Amelina, E. Carmel, A. Runfors, \& E. Scheibelhofer (Eds.), European social citizenship. Regulations, discourses and experiences of transnational social security (pp. 113-132). Routledge.

Römer, F. (2017). Generous to all or "insiders only"? The relationship between welfare state generosity and immigrant welfare rights. Journal of European Social Policy, 27(2), 173-196.

Ruist, J. (2014). Free immigration and welfare access: The Swedish experience. Fiscal Studies, 35(1), 19-39.

Runfors, A., Fröhlig, F., \& Saar, M. (2016). A comparative analysis of the portability of social security rights within the European Union. Estonia-Sweden case study (WSF Policy Brief). University of Bath.

Ryan, L. (2011). Transnational relations: Family migration among recent Polish migrants in London. International Migration, 49(2), 80-103.

Sabates-Wheeler, R., \& Koettl, J. (2010). Social protection for migrants: The challenges of delivery in the con- text of changing migration flows. International Social Security Review, 63(3/4), 115-144.

Sabates-Wheeler, R., Koettl, J., \& Avato, J. (2011). Social security for migrants: A global overview of portability arrangements. Rethinking International Development Series, 91, 91-116. https://doi-org.uaccess. univie.ac.at/10.1057/9780230306554_4

Sainsbury, D. (2006). Immigrants' social rights in comparative perspective: Welfare regimes, forms in immigration and immigration policy regimes. Journal of European Social Policy, 16(3), 229-244.

Scheibelhofer, E. (2008). Combining narration-based interviews with topical interviews: Methodological reflections on research practices. International Journal of Social Research Methodology, 11, 403-416.

Scheibelhofer, E. (2016). Reflecting on spatiality in European migration research: From methodological nationalism to space-sensitive observations of social transformations. In A. Amelina, K. Horvath, \& B. Meeus (Eds.), An anthology of migration and social transformation (pp. 73-86). Springer.

Scheibelhofer, E., \& Holzinger, C. (2018). “Damn it, I am a miserable Eastern European in the eyes of the administrator": EU migrants' experiences with (transnational) social security. Social Inclusion, 6(3), 201-209. https://doi.org/10.17645/si.v6i3.1477

Schmidt, S. K., Blauberger, M., \& Martinsen, D. S. (2018). Free movement and equal treatment in an unequal union. Journal of European Public Policy, 25(10), 1391-1402. https://doi.org/10.1080/ 13501763.2018.1488887

Schmitt, C., \& Teney, C. (2019). Access to general social protection for immigrants in advanced democracies. Journal of European Social Policy, 29(1). https://doi. org/10.1177\%2F0958928718768365

Seeleib-Kaiser, M., \& Pennings, F. (2018). Intra-EU migration and social rights: An introduction. In F. Pennings \& M. Seeleib-Kaiser (Eds.), EU citizenship and social rights: Entitlements and impediments to accessing welfare (pp. 1-10). Edward Elgar Publishing.

Serra Mingot, E., \& Mazzucato, V. (2018). Providing social protection to mobile populations: Symbiotic relationships between migrants and welfare institutions. Journal of Ethnic and Migration Studies, 44(13), 2127-2143. https://doi-org/10.1080/ 1369183X.2018.1429900

Serra Mingot, E., \& Mazzucato, V. (2019). Moving for a "better welfare"? The case of transnational Sudanese families. Global Networks, 19(2), 139-157.

Shutes, I., \& Walker, S. (2018). Gender and free movement: EU migrant women's access to residence and social rights in the UK. Journal of Ethnic and Migration Studies, 44(1), 137-153.

Smith, S. R. (2003). Street-level bureaucracy and public policy. In W. Bartley Hildreth, G. Miller, \& E. L. Lindquist (Eds.), Handbook of public administration (pp. 354-365). Routledge.

Soysal, Y. N. (1994). Limits of citizenship: Migrants and 
postnational membership in Europe. University of Chicago Press.

Spehar, A., Hinnfors, J., \& Bucken-Knapp, G. (2017). Passing the buck: The case of failing multilevel governance and vulnerable EU migrants in Sweden. De Gruyter.
Tonkiss, K. (2019). Locating the post-national activist: Migration rights, civil society and the practice of post-nationalism. Ethnic and Racial Studies, 42(2), 159-177.

Witzel, A., \& Reiter, H. (2012). The problem-centred interview. SAGE.

\section{About the Author}

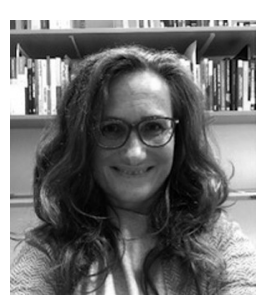

Elisabeth Scheibelhofer is an associate professor of sociology (University of Vienna) working on migration, mobility, and qualitative methods. She is currently leading the research project DEMICO (2021-2024) which is looking at dequalification from a qualitative longitudinal approach. This is a follow-up project of a broader international collaboration (transwel.org, 2015-2018) covering EU migrants' transnational access to social security rights. She has published extensively on a range of issues within migration research and qualitative methodologies. 